\title{
ENTREPRENEURIAL COMPETENCIES DEVELOPMENT MODEL ON SMALL MEDIUM TOURISM ENTERPRISES (SMTES)
}

\author{
Hamidah Nayati Utami \\ Department of Bussiness Administration, Universitas Brawijaya, Malang, Indonesia \\ Email: hamidahn@ub.ac.id \\ hamidahutami@gmail.com
}

\begin{abstract}
Fokus penelitian ini diarahkan untuk mengetahui kompetensi kewirausahaan pelaku UKM di sektor pariwisata, mengidentifikasi masalah pengembangan kompetensi dan merumuskan model pengembangan kompetensi pelaku SMTEs dalam mendukung terwujudnya industri pariwisata berkelanjutan. Penelitian dilakukan di Kawasan Strategis Pariwisata Nasional (KSPN) Bromo Tengger Semeru Jawa Timur Indonesia. Metode penelitian menggunakan pendekatan kualitatif dengan teknik analisis deskriptif, pengumpulan data dilakukan dengan wawancara mendalam dengan Organisasi Perangkat Daerah dan pelaku UKM sektor pariwisata. Hasil penelitian ini menunjukkan bahwa: tingkat entrepreneurial competence baik berupa pengetahuan, ketrampilan maupun sikap kewirausahaan yang dimiliki oleh pelaku UKM sektor pariwisata masih tergolong rendah; salah satu faktor yang mempengaruhi rendahnya kompetensi adalah kurang optimalnya peran pemerintah dalam meningkatkan entrepreneurial competence, pola koordinasi antar organisasi perangkat daerah belum berjalan dengan baik dan belum terlibatnya seluruh stakeholder dalam melakukan pengembangan. Oleh karena itu model yang diusulkan untuk mengembangkan kompetensi entrepreneurial SMTE adalah pendekatan collaborative governance secara berkesinambungan.
\end{abstract}

Key Words: kompetensi kewirausahaan, pariwisata, UKM pariwisata, Bromo Tengger Semeru

\begin{abstract}
The focus of this research is directed at identifying the entrepreneurial competence of SMTEs in the tourism sector, identifying competency development problems, and formulating competency development models of SMTE players in supporting the realization of the sustainable tourism industry. The study was conducted in the National Tourism Strategic Area (KSPN) Bromo Tengger Semeru, East Java, Indonesia. The research method uses a qualitative approach with descriptive analysis techniques, data collection is done by in-depth interviews with the government officials of local government organizations some SMTE Owners. The results of this study indicate that: the level of entrepreneurial competence, namely knowledge, skills and entrepreneurial attitudes of the tourism sector SMTEs is still relatively low; One of the factors that influence the low competency is the less optimal role of the government in increasing entrepreneurial competence, the pattern of coordination between regional organizations has not gone well and all stakeholders have not been involved in developing. Therefore, the proposed model for developing SMTE's entrepreneurial competencies is a collaborative governance approach on an ongoing basis.
\end{abstract}

Key Words: entrepreneurial competence, tourism, SMTEs, Bromo Tengger Semeru 


\section{INTRODUCTION}

The tourism sector has proven to be able to be one of thr sector that contribute to the country's economy, job creation, and improve the welfare of the community (Lorio and Corsale, 2010; Liu, et. Al, 2018). Previously, Mshenga \& Owuor (2009) stated that the tourism sector would be more optimal in contributing to economic development, increasing income and community welfare, able to reduce poverty if in the process of tourism development linking with the local economic activities of society such as agriculture and SMTEs. The World Travel and Tourism Council Survey (2019) states that Travel and Tourism is one of the largest industrial sectors in the world and creates many jobs for the community. This sector also generates new business opportunities not only in cities and developed countries but also in many developing countries, providing economic benefits and employment to various rural areas. Furthermore, the Travel and Tourism sector is the second-fastest-growing sector in 2018 at $3.9 \%$, only slightly behind Manufacturing, which grew by $4.0 \%$, both of which are faster than the global economic growth of $3.2 \%$. Worldwide, more than 319 million jobs were generated from the Travel \& Tourism sector. This represents $10.0 \%$ of all jobs, or one out of every ten jobs worldwide. The Travel and Tourism sector has been able to create one out of every five new jobs throughout the world over the past five years (WTTC, 2019). For Indonesia, in 2017 the tourism sector has been able to create $3,468,440$ or $2.9 \%$ of total employment and contribute to the Gross Domestic Product of US \$28,208.9 Million or $3.3 \%$ of total GDP.

However, tourism development in Indonesia is not optimal and needs to be improved. The findings of the Calderwood and Soshkin (2019) show that Indonesia's tourism competitiveness ranks 40th out of 140 countries surveyed. At the ASEAN level, this position is still inferior to Singapore (ranked 17), Malaysia (29), and Thailand (31). One indicator in determining tourism competitiveness is the human resources and labor market where Indonesia's position is ranked 44th, the position is also still below Singapore (ranked 5), Malaysia (15), Thailand (27), and even the Philippines (37). As we know the indicators of the human resources and labor market are assessed from the role of the government and the private sector to collaborate in developing the quality of all human resources involved in tourism development through various education, training, and assistance in the context of sustainable development of knowledge and skills. The tourism sector SMEs are one of the human resources that have direct involvement in tourism development.

Research by Buhalis and Peter (2011) mentions that there are 6 (six) characteristics that must be possessed by SMEs in the tourism sector (Small Medium Tourism Entreprise SMTEs) in order to be competitive, namely: (a) entrepreneurs' motivation, SMTEs actors must have great entrepreneurial determination through hard work and sacrifice; (b) market niche advantages, optimizing profitable niche markets through special products and / or services according to the wishes of consumers; (c) Personal relationship with enterprise stakeholders, the ability to build a family relationship between SMEs and stakeholders (suppliers, distributors, employees) who help each other especially during difficult times; (d) family involvement, optimizing family-based human resources can be used flexibly so that it can meet the availability of products / services specifically requested by customers; (e) flexibility, SMTEs must have high flexibility in managing changes in the external environment so that they can make decisions quickly in accordance with market changes; (f) continuity, family business-based SMTEs must ensure the determination to continue running the business in a sustainable manner. These six characters will be optimal if balanced with entrepreneurial competencies possessed by each SMTEs actor.

The Tanoira and Valencia Study (2014) states that the ability to innovate is one of the reasons for the low competitiveness of SMEs. The products and services produced are hereditary knowledge, no new technological touches. Therefore, knowledge, abilities, attitudes, skills, and capacity are needed to innovate both products and services so that the presence of SMEs does not only benefit the actors themselves but also the regional economy. Furthermore, Tanoira and Valencia (2014) also found that there was a strong correlation between competence and business performance. The competence in question is improving the quality of entrepreneurship, the courage to take risks, the ability to collaborate 
with other parties, to the ability to provide excellent service for consumers. That is, knowledge management programs and entrepreneurial competencies become factors that need attention in improving business performance. Collaboration between the government, investors, and academics in transferring technology to SMEs will also encourage the growth of innovation.

Lawal, et al (2018) found that entrepreneurial competence was a strong predictor in improving business performance. The better the entrepreneurial competence of SMEs, the better the ability to manage changes in an increasingly dynamic and complex business environment. Therefore, a collaboration between SMEs and the government will encourage the realization of a sustainable business ecosystem. SMEs must continue to improve entrepreneurial competence in capturing, managing, and exploiting every business opportunity that exists. As for the government, it is necessary to encourage the creation of a business climate oriented towards entrepreneurship development through strengthening entrepreneurial skills and knowledge (Lawal, et al, 2018). That is, there must be a shared awareness about the importance of increasing knowledge, skills, analysis of needs and opportunities, to the right institutional patterns in directing SME actors. More initiatives and collaborative collaboration between SMEs and the government at all levels and all types of businesses related to tourism are needed. This is needed to exploit the potential of the tourism market so that SMEs get a more competitive position in the domestic and international markets through tourism activities (Gregoric and Pajic, 2016). One collaboration approach that can be developed through collaborative governance.

The Bromo Tengger Semeru (BTS) National Tourism Strategic Area (KSPN) is one of the ten KSPN in Indonesia. Lumajang Regency as one of the hosts certainly has great potential in utilizing the existence of BTS destinations, especially in creating employment opportunities for SMEs. Noted, during 2017 there were 551,346 domestic tourists and 22,602 foreign tourists visiting the BTS destination area. While the number of tourists visiting the Ranupane destination which is close in the BTS area has also increased although only about $30 \%$ of tourists visiting the BTS can be "withdrawn" to be able to visit Ranapani 7). That is, tourists, visiting the BTS destination area and its surroundings become a definite market niche for SMEs if they can optimize it. This study seeks to explore the barriers and encouragement of tourism SMEs in increasing their entrepreneurial competence and design models of entrepreneurial competency development of tourism sector SMEs as an alternative policy recommendation for the government so that it can sustainably improve SME performance while building a resilient tourism industry.

\section{METHODS}

.......This study uses a qualitative approach. The focus of this research was a description of the entrepreneurial competence of SMTEs in the tourism sector, competency development problems, formulation of competency development models of SMTE players in supporting the realization of the sustainable tourism industry. Data collection was direct observation, documentation, and strengthened by in-depth interviews. The information of this research consists of SMTEs owner, government officials from 4 (four) local government organizations (OPD) related to tourism (Office of Tourism and Culture, Office of Cooperatives and Small and Medium Enterprises, Department of Industry and Trade, and Department of Labor of Lumajang Regency). This research was conducted in July 2019 until October 2019. Data analysis techniques were carried out in four stages, namely data collection, data reduction, data presentation, and finally conclusion drawing (Miles, et al, 2013).

\section{RESULT AND DISCUSSION \\ Entrepreneurial Competence of SMTEs and The Problems}

......Thomas, et al (2002) revealed that entrepreneurial competence is a characteristic that includes the skills, knowledge, and personality traits that are key to the success of entrepreneurs in running their businesses. The use of the entrepreneurial competence approach is one way to assess the performance and sustainability of a business organization. However, not all SMTEs have comprehensive entrepreneurial competencies, so it is not uncommon for businesses initiated by SMTEs to not have long business sustainability. 
Many SMTEs also change their business types in line with changes in market trends so that they are impulsive. This also happened to SMTEs in the tourism sector in Lumajang Regency. The presence of tourists visiting Bromo, Tengger, and Semeru (BTS) destinations has not been thoroughly optimized due to the weak understanding of entrepreneurial competencies as conveyed by coffee business owners in the destination area:

\begin{abstract}
"We don't have a good understanding of how to manage a business. During this time the business is managed as much as we can and is self-taught, sometimes we also change the type of business to adjust what season is trending in the community. The main objective of our business is to get benefits that can be used to fulfill our daily needs. "
\end{abstract}

A similar sentiment was also conveyed by the homestay business owner in the BTS area which stated that the business carried out was a hereditary business, no formal education was obtained during running the business.

\section{"We do not have the skills in marketing homestays to tourists, so many tourists who come prefer to stay in hotels. Besides, communication skills and innovation also do not have so that the business management we do practice because of learning by myself"}

This shows that SMTEs do their business only based on need, not because of the desire to become an entrepreneur so that business performance and business sustainability, in the long run, cannot be measured. This is in line with the findings of Vallabh (2017) which reveal that entrepreneurial skills are a serious obstacle to the development of SMTEs, especially in terms of business management carried out by SMTEs in the tourism sector. This has an impact on the weak business climate, especially businesses that support tourism, which is one of the encouragements of tourists to visit a destination. On the other hand, this condition also impacts on the weak competitiveness of SMTEs.

Furthermore, one of the factors that cause the weak entrepreneurial capacity of tourism SMTEs in the tourism sector is the lack of optimal support from the government as a party that acts as a dynamic and facilitator in assisting the business development of SMTEs. As explained earlier, in Lumajang Regency, there are 4 (four) local government organizations (OPD) that have a connection with the development of SMTEs, namely the Office of Cooperatives and SMEs which have a direct link with the process of growth and development of SMTEs, the Trade Office which has a link creating market opportunities for products/services produced by SMTEs, the Office of Culture and Tourism which has a duty in tourism development where one of the supporting pillars in the tourism industry, and the Department of Manpower which focuses on creating business opportunities, especially in the tourism sector. The four local government organizations have tried to help develop the entrepreneurial competencies of SMTEs, especially in the tourism sector through various pieces of training. However, the training provided tends to be program-based and does not touch the needs of SMTEs. This was acknowledged by government representatives from the Office of Cooperatives and SMEs

\footnotetext{
"The Office of Cooperatives and SMEs have conducted some basic training and capital assistance for SMEs. The training that we have provided has not yet reached the increase in knowledge related to HR management, risk management, and financial literacy that are the needs of SMEs to improve and develop their businesses. We also don't have a special program that targets SMEs in the tourism sector"
}

The same thing also happened in the Office of Trade and the Agency of Manpower which does not yet have a grand design for developing entrepreneurial competence of SMTEs in the tourism sector. The role that is taken at this time is still based on programs and activities from the perspective of the government in the form of entrepreneurship motivation training to facilitate product exhibitions. There is no specific training that can improve entrepreneurial knowledge, skills, and attitudes. It is not uncommon for trainees in one Agency to be SME practitioners who have participated in the same training in other agencies so that the benefits of the training are only felt by a few 
SMTEs.The role of the government in enhancing entrepreneurial competence is mostly carried out by the Office of Tourism and Culture. One significant role is to provide training and mentoring for the establishment of homestay businesses managed by communities who are members of the Tourism Awareness Group (Pokdarwis). However, the sustainability of assistance has not been carried out optimally so that homestay SMTEs have difficulty competing with large businesses (hotels) because they do not have special skills in terms of marketing, interpersonal skills, business strategy development, up to the utilization of market opportunities. Based on these results, it can be seen that there is a need for good collaboration between SMEs and the government as found by Lawal, et al (2018) which states that the government needs to create a business climate oriented towards entrepreneurship development through strengthening entrepreneurial skills and knowledge while SME actors must also have a strong desire to increase entrepreneurial capacity sustainably.

Lack of Collaborative between Local Government Agency

Various studies have shown that the government plays an important role in the development of SMTEs. This role is manifested in various government programs and activities intended to increase the capacity and capability of SMTEs in developing their businesses. However, the sectoral egos of each government agency remains a challenge in the process of implementing the government's role. Lack of coordination, overlapping programs between agencies, so that the attitude of waiting for each other is an obstacle in the development of SMTEs, especially related to increasing entrepreneurial competence. As stated by the Agency of Trade who chose the attitude to wait for tourism development plans from the Office of Tourism and Culture rather than initiating to improve the ability of SMEs in the tourism sector.

"We are still waiting for the tourism development plan conceptualized by the Office of Tourism and Culture so that our program for SMEs has not specifically touched SMEs in the tourism sector"

On the other hand, the Office of Tourism and Culture which has a main function in the tourism sector also considers that the task of increasing the competence of SMEs working in the tourism sector is not a task that they must do because their main authority is limited to tourism development.

"Our focus is currently still at the stage of developing tourism destinations and marketing, while for the tourism industry we are limited to providing training to the Tourism Awareness Group (Pokdarwis) and people who have businesses in the destination area. As for the development of entrepreneurial competencies, SMTEs are not our main authority even though they have businesses in the tourism sector".

This shows that the pattern of communication and coordination between government agencies is still weak. Though the mandate of Government Regulation Number 50 of 2011 concerning the National Tourism Development Master Plan that there are 4 main pillars in tourism development namely tourism destinations, tourism marketing, tourism industry, and tourism institutions. All four pillars must be carried out by all relevant government agencies so that the development of the tourism industry must involve the Office of Cooperatives and SMEs and the Office of Trade both of which have functions in managing the business climate of SMEs. The lack of strong collaboration patterns across the government agencies has an impact on the weak acceleration of business managed by SMEs in the tourism sector. Therefore, a pattern is needed that can encourage the creation of a collaboration between government agencies related to tourism, especially for improving the entrepreneurial competence of SMTEs.

......The collaborative program process between agencies in the Lumajang Regency government that has a connection in developing the entrepreneurial competence of SMTEs in the government sector can be described as follows. 


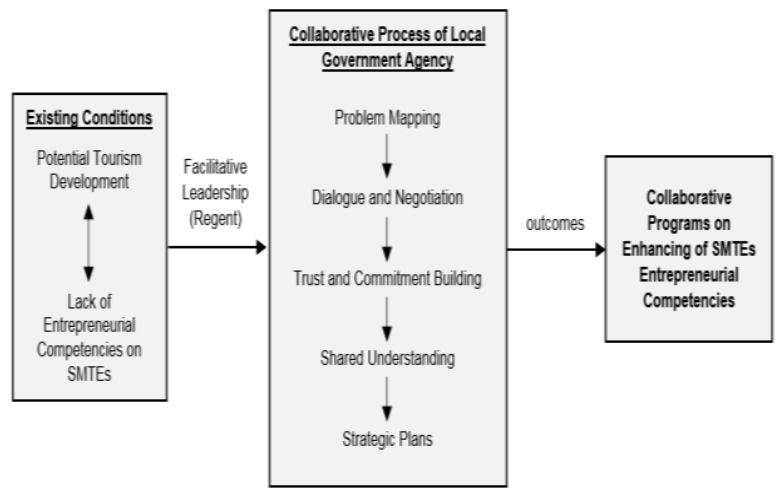

Figure 1. Program Collaboration Process between Regional Organizations

Figure 1 shows that the current condition of Lumajang Regency has a large tourism potential but has not been able to make a major contribution to the regional economy and job creation due to the weak entrepreneurial competencies possessed by tourism sector SMTEs. On the other hand, the government tends to have a high sectoral ego so that work programs are not well integrated between local government organizations. A collaborative process between local government organizations is needed which is facilitated directly by the Regional Head to produce a joint strategic plan so that it is expected to produce a collaborative program to jointly improve the entrepreneurial abilities of SMTEs in the tourism sector.

\section{Entrepreneurial Competencies Development Model on SMTEs}

......The development of entrepreneurial competencies must be able to translate aspects of knowledge, skills, and attitudes that must be possessed by every tourism SME actors in the sector. Entrepreneurial knowledge is focused on: (a) knowledge of organizational management, and (b) knowledge of HR management, marketing, risk management, and financial literacy. Whereas entrepreneurial skills must be able to improve: (a) Marketing Skills: utilization of the marketplace, market research, marketing techniques, the ability to establish relationships with consumers, the ability to form partnerships, make cooperation contracts, collaborate; (b) Opportunity Skill: skills to take advantage of opportunities, create ideas, markets or products, product/service development skills; (c) Resource Skills: skills in preparing a business plan, financial plan, analytical and calculation skills, careful decision making, managing risks; (d) Interpersonal Skill: the skills to lead and influence subordinates, motivate subordinates, manage people and manage conflicts; (e) Learning Skill: adapting skills in new environments, adapting to uncertainty, actively learning new things, and (f) Strategic Skills: skills in setting goals, skills in setting priorities. Furthermore, the development of entrepreneurial attitudes can be achieved through increasing: (a) Confidence \& motivation for success; (b) adaptive and proactive attitude towards change; (c) creative in solving problems, and (d) perseverance in trying. The development of entrepreneurship competencies above is not the responsibility of the government alone, but SMTEs as both subject and object must have a strong commitment to continuously improve their entrepreneurial capacity. Besides, support from various actors such as academics, the private sector, and the community that is concerned about the tourism sector will be able to accelerate the realization of a tourism industry that is based on local economic strength while at the same time contributing economically to SMTEs and local government.

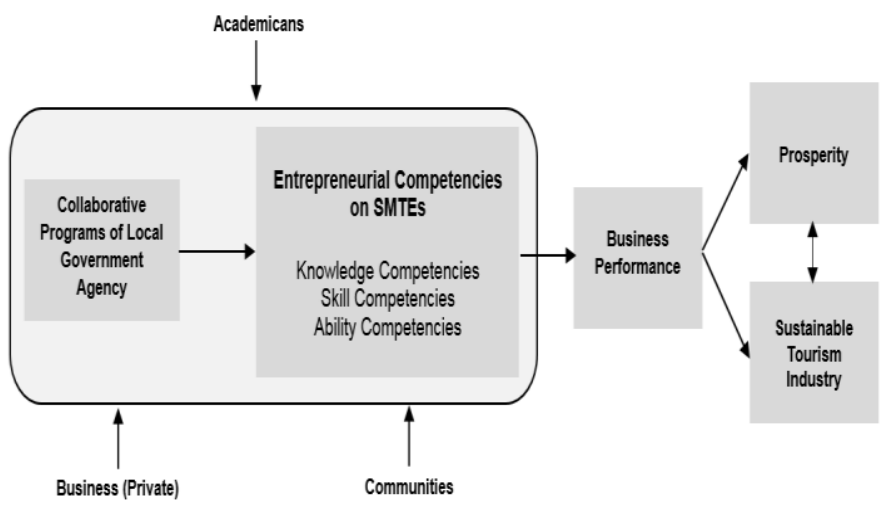

Figure 2. Entrepreneurial Competencies Development Model on SMTEs

\section{CONCLUSIONS AND RECOMMENDATIONS}

The results of this study indicate that entrepreneurial competence is a major challenge for $\mathrm{HR}$ in the tourism sector, especially for SMTEs in improving business performance while encouraging the growth of resilient tourism industry. The development of entrepreneurial competencies carried out integrally both knowledge, skills, and 
entrepreneurial attitudes that must be owned by SMTEs as a foundation in managing their business activities.

The leverage between stakeholders to collaborate in enhancing the entrepreneurial capacity of SMTEs in which the government acts as a dynamic actor. In the government sector itself, it is necessary to have a Regional Action Plan specifically related to tourism development so that local government organizations that have a link in tourism development, especially the tourism industry sector, have a common vision and goal so that all programs and activities support one another. Further research is needed on the importance of collaborative governance in enhancing the entrepreneurial competence of SMTEs in the tourism sector.

\section{REFERENCES}

Bramwell, B., \& Lanae, B., (2011) Critical research on the governance of tourism and sustainability, Journal of Sustainable Tourism, 19:4-5, $411 \quad-\quad 421$, https://doi.org/ 10.1080/09669582.2011.580586

Buhalis, D., \& Peter, M., (2011) SMEs In Tourism, In Buhalis, D., \& Costa C., Tourism Management Dynamics: Trends, Management, and Tools, pp (116-129) Routledge.

Carayannis, E.G., Barth, T.D. \& Campbell, D.F. (2012) The Quintuple Helix innovation model: global warming as a challenge and driver for innovation. J Innov Entrep 1, 2. 1-12 https://doi.org/10.1186/21925372-1-2

Cooper, C., Fletcher, J., Fyall, A., Gilbert, D., Wanhill, S., (2017). Tourism: Principles and Practice, Sixth Edition, Longman.

Gregoric, M., \& Pajic, A.K., (2016). The Impact of Small Medium Entrepreneurship on Tourism Development $\mathrm{n}$ The Republic of Croatia. Journal of Business Paradigms. 1 (1) 85-94,

Lawal, F., Iyiola, O., Adegbuyi, O., Ogunnaike, O., \& Taiwo, A., (2018). Modeling the relationship between entrepreneurial climate and venture performance: The moderating role of entrepreneurial competencies. Academy of Entrepreneurship Journal. 24 (1) 1-15

Liu, S.; Cheung, L.T.; Lo, A.Y.; Fang, W. (2018). Livelihood Benefits from PostEarthquake Nature-Based Tourism Development: A Survey of Local Residents in Rural China. Sustainability 2018, $\quad 10 \quad$ (3), 699. https://doi.org/10.3390/su10030699.

Iorio, M., \& Corsale, A., (2010). Rural Tourism and Livelihood Strategies in Romania. Journal of Rural Studies. 26. 152-162. https://doi.org/10.1016/j.jrurstud.2009.1 0.006

Miles, M. B., Huberman, A. M., \& Saldana, J. (2013). Qualitative data analysis, A methods sourcebook, Third Edition, Sage Publication.

Tanoira, F.G.B., (2014). Knowledge management, entrepreneurial competencies, and organizational development in micro and small enterprises in rural regions in the state of Yucatan, Mexico. European Scientific Journal. 10 (1) 177-193

Vallabh, D., (2017). Skills as Impediment to Small and Medium Tourism Enterprises (SMTEs), Eastern Cape, South Africa. African Journal of Hospitality, Tourism, and Leisure. 6. 1-8.

Calderwood, L.U., \& Soshkin, M., (2019) (2019). The travel and tourism competitiveness report. World Economic Forum. http://www3.weforum.org/docs/WEF_T TCR_2019.pdf

World Travel \& Tourism Council. (2019). Travel and Tourism Global Economic Impact and Trend 2019. http://ambassadeethiopie.fr/onewebmedia/TourismWTTC-Global-Economic-ImpactTrends-2019.pdf 